\title{
TAXONOMIC STUDIES IN THE GENUS DISPERIS (ORCHIDACEAE) IN SOUTHEAST ASIA
}

\author{
H. KURZWEIL \\ Compton Herbarium, South African National Biodiversity Institute, \\ 7735 Claremont, South Africa; e-mail: kurzweil@sanbi.org
}

\begin{abstract}
SUMMARY
The taxonomy of the Asian species of the genus Disperis (Orchidaceae) was examined. Following study of material from throughout the distribution range all previously recognised Asian taxa were considered synonymous, and therefore only one widespread species D. neilgherrensis Wight is recognised. While most plant parts are merely highly variable in their size, the structure of the lip appendage is not uniform in the Indian specimens.
\end{abstract}

Key words: Orchidaceae, Disperis, Asian species, taxonomy.

\section{INTRODUCTION}

Disperis is a genus of terrestrial orchids within subfamily Orchidoideae (Pridgeon et al., 2001). The genus is well represented in Africa and Madagascar as well as on adjacent Indian Ocean islands with about 70 species (Verdcourt, 1968; Geerinck, 1984; La Croix \& Cribb, 1995; Manning, 1999; La Croix et al., 2002). Furthermore, the genus has also been recorded from several widely scattered localities in tropical Asia, ranging from India to Thailand, the Philippines and New Guinea (Seidenfaden, 1969: 103). The flowers of the genus are known for their extremely complicated structure, with various parts fused or adnate to each other and the lip bearing a highly elaborate appendage (Kurzweil \& Linder, 1991). In the course of a systematic study of the entire genus it was necessary to examine the non-Afromadagascan species.

\section{RESULTS}

Ten species were originally described in various parts of Asia. Morphological studies of more than 60 dry herbarium and pickled specimens covering the Asian part of the distribution area, as well as literature data, reveal that the diversity is continuous and is apparently merely the result of infraspecific variation (Table 1). It is also suggested that other characters that were in the past used to delimit species in the group, such as cuspidate petals and marginally undulate lateral sepals, are insufficient for the recognition of separate species. Therefore, all Asian species are placed under the synonymy of the oldest taxon $D$. neilgherrensis which is a widespread and very variable species. This concept corresponds well with the views of Seidenfaden (1969: 103) and Matthew (1983: 1569). 


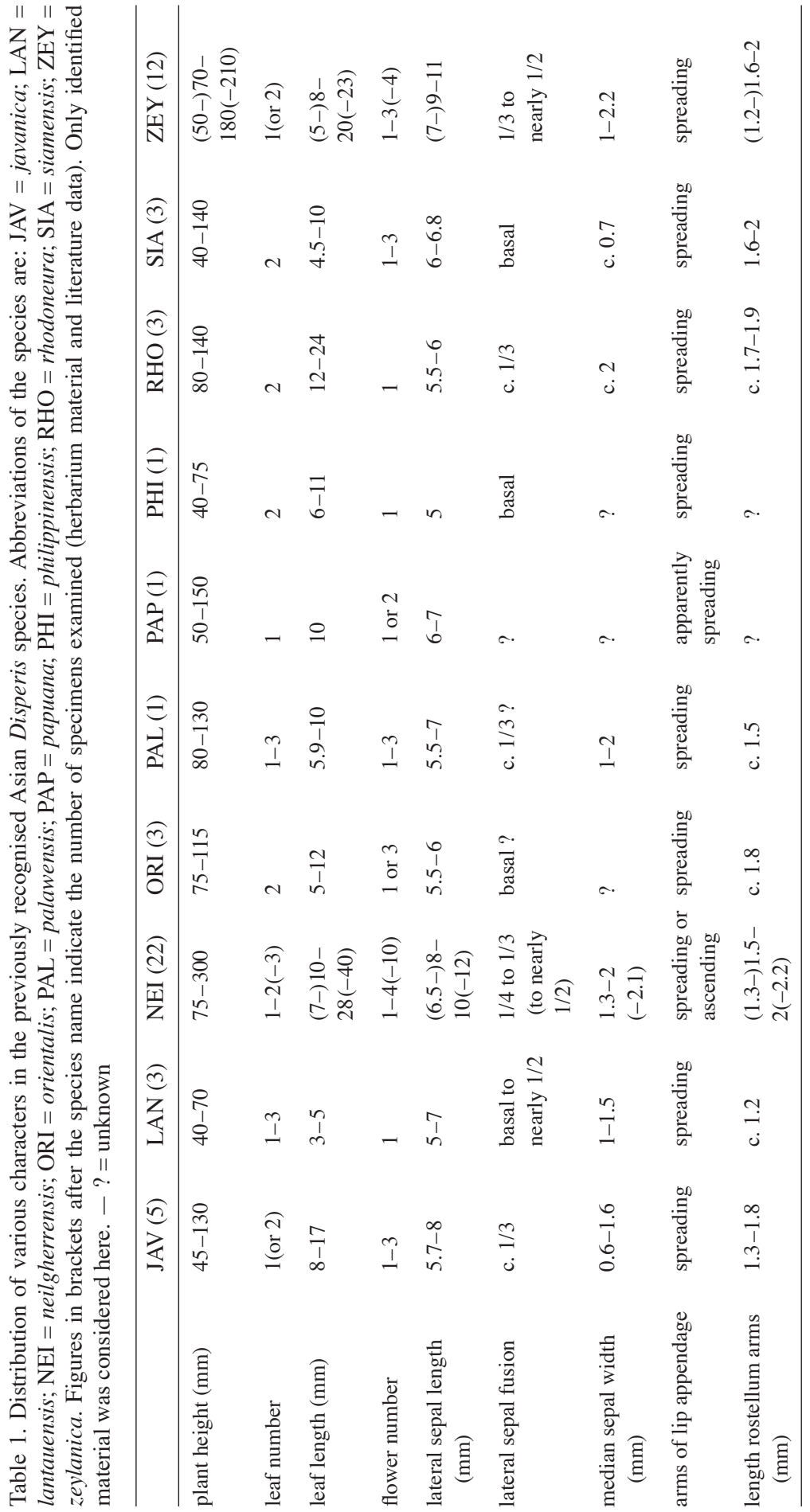




\section{Disperis neilgherrensis Wight - Fig. 1}

Disperis neilgherrensis Wight (1851) 15, t. 1719; Hook.f. (1894) 169; Schltr. (1898) 931; Kraenzl. (1900) 838; C.E.C. Fisch. (1928) 1478; K.M. Matthew (1983) 1569; Pradhan (1979) 676, as 'nilgirensis Wight'. - Disperis zeylanica Trimen var. nilgirensis (Wight) Pradhan (1976) 42. - Lectotype (designated here): Wight 3018 (holo K; iso AMES, C, S, W), South India, Coimbatore, date not cited. [See note 1.]

Disperis zeylanica Trimen (1885a) 245; (1885b) 91; Hook.f. (1894) 169; Pradhan (1976) 42; Jayaw. (1981) 381. - ?Syntypes: Walker 16 (icono K), Sri Lanka: near Rambodde, date not cited; Walker $180(\mathrm{~K})$, Sri Lanka, date not cited.

?Disperis papuana Michol. \& Kraenzl. in Kraenzl. (1900) 844. - Type: Micholitz (not found), Moluccas, 'Timorlaut- oder Tenimber-Insel', March 1897. [See note 2.]

Disperis rhodoneura Schltr. (1905) 81; R.S. Rogers, H.J. Katz \& J.T. Simmons (1982) 77. — Type: Schlechter 14332 (not found), north-western Papua New Guinea, Torricelli Range, 18 Apr. 1902.

Disperis philippinensis Schltr. (1911) 436. - Type: Merrill 4215 (iso AMES), Philippines, Luzon, Mt Arayat, Sept. 1905.

Disperis javanica J.J. Sm. (1914) 19; (1922) t. 21; J.B. Comber (1990) 71. - Type: Backer 6765 (BO, n.v.), Java, Lawoe, near Djogorogo, Feb. 1913.

Disperis siamensis Rolfe ex Downie (1925) 422; Seidenf. \& Smitinand (1958-1965) 53; Seidenf. (1969) 101; F. Maek. (1974) 308; Seidenf. (1977) 139; T. S. Liu \& H.J. Su (1978) 977. — Type: Kerr 1987 (holo K; iso C), Thailand, Doi Suthep, 27 Aug. 1911.

Disperis orientalis Fukuy. (1936) 17. - Type: Fukuyama 4839 (Herb. Orch. Fuk., n.v.) Taiwan, Kôtô-syo, 25 July 1935.

Disperis palawensis (Tuyama) Tuyama (1940) 267. - Stigmatodactylus? palawensis Tuyama (1939) 57. - Pantlingia palawensis (Tuyama) Rauschert (1983) 434. - Type: Tuyama s.n. (not found), Caroline Islands, Pulau, 4 Sept. 1937. [See note 3.]

Disperis lantauensis S. Y. Hu (1972) 17; S. C. Chen, Z.H. Tsi \& Y.B. Luo (1999) 194, as 'nantauensis'. - Type: Hu 10812 (holo ?AA), Hong Kong, Lantau Island, 30 July 1970.

Disperis tripetaloides sensu Lindl. p.p. (1839) 371. [See note 4.]

Disperis teleplana F. Maek. (1974) 307, nom. nud. [See note 5.]

Disperis walkeriana Rchb.f. mss. (fide Schlechter, 1898: 932).

Disperis monophylla B. Blatter, mss. [See note 6.]

Disperis sulphurum, mss. [See note 7.]

Disperis lunata, mss. [See note 8.]

Terrestrial herbs, variable in height from $40-250(-380) \mathrm{mm}$, slender to semi-robust; tubers small, globose or elongate, 3-15 $\mathrm{mm}$ diam. and up to $20 \mathrm{~mm}$ long, pilose; subterraneous stem 15-30 mm long, above-ground stem green and often flushed with purple or brown, glabrous, often swollen at base. Leaves: 2 pale basal membranous sheaths present, foliage leaves $1-3$, cauline, alternate, ovate-cordate or reniform-cordate, $3-30(-43)$ by $3-25(-31) \mathrm{mm}$, acute or obtuse, amplexicaul, green or reddish green and underside sometimes purple, glabrous, indistinctly petiolate, petiole mostly sheathing, 1.5-8(-15) mm long; leaves of non-flowering plants 2, subopposite. Inflorescence a lax terminal raceme, with 1-5 (rarely up to 10) flowers; bracts leaf-like, $5-17(-23) \mathrm{mm}$ long, becoming smaller towards inflorescence apex. Flowers resupinate, small or medium-sized, 5-18 $\mathrm{mm}$ across, white to pink or light purple, rarely greenish, often with darker markings, lip appendage and apical lip callus mostly yellow; pedicel and ovary cylindrical, 6-25 mm long, pedicel not clearly differentiated; unpleasant scent recorded by Smith (1914). Median sepal erect, narrowly lanceolate, 5-14 by $0.7-2.2 \mathrm{~mm}$, acute or subacute, adnate to petals to form shallow hood 4-10 by $3-9 \mathrm{~mm}$, hood with reflexed margins. Lateral sepals pendent, ovate-lanceolate, 

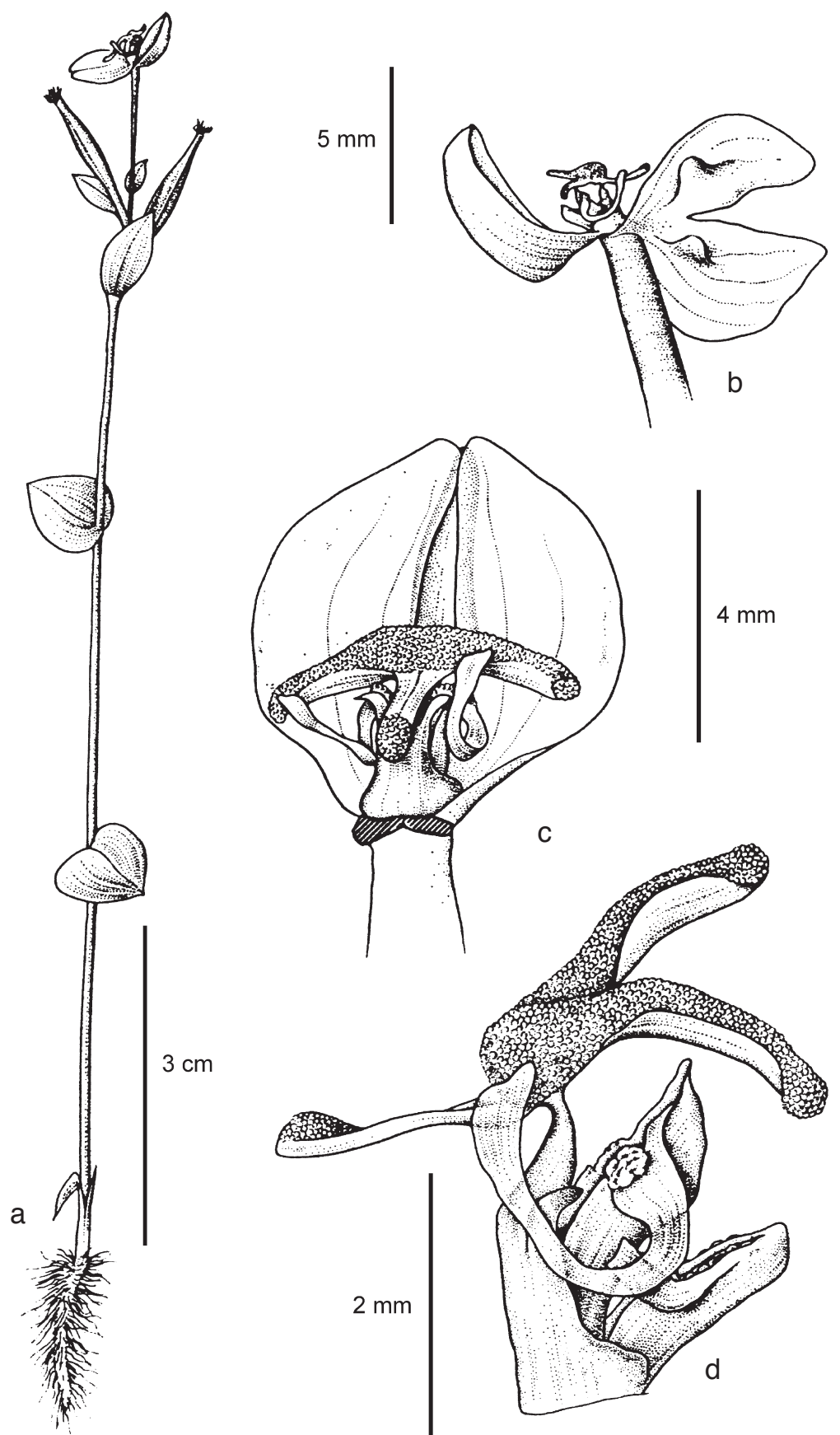

C

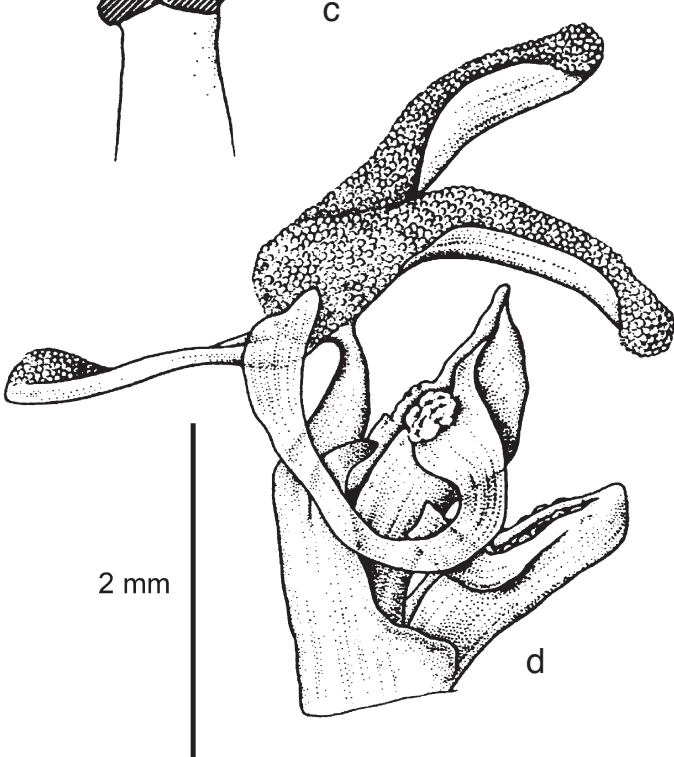

Fig. 1. Disperis neilgherrensis Wight. a. Habit (tuber broken off); b. flower in side view; c. flower in front view with lateral sepals removed; d. lip and gynostemium (Larsen FTP 925; reproduced from Seidenfaden, 1969: 102, with the kind permission of the copyright holder). 
$5-12(-15)$ by $1.5-6(-8) \mathrm{mm}$, obtuse or subacute, fused in basal $1 / 4$ to $1 / 2$, margins sometimes undulate, basally sometimes pubescent, with shallow conical sacs up to c. $2.5 \mathrm{~mm}$ long in lower half. Petals broadly ovate-lanceolate or broadly semi-lunulate, $5.5-14$ by $2-5 \mathrm{~mm}$, subobtuse. Lip with narrow claw $1.5-3 \mathrm{~mm}$ long which is basally fused with gynostemium; blade rotund, occasionally slightly emarginate, on flat stalk $0.2-0.7 \mathrm{~mm}$ wide, total length of blade and stalk $2-3(-5) \mathrm{mm}$, lip blade with tomentose median crest; lip appendage as two lateral processes which are mostly horn-like and spreading, rarely ascending and flat, usually tomentose. Gynostemium $1.5-3 \mathrm{~mm}$ long; anther reflexed, 1.2-2 mm long, with parallel adjacent thecae, auricles small; stigmas as two transversally arranged lanceolate pads on sides of central rostellum lobe just above point of insertion of lateral arms; central rostellum lobe flat and covering anther, emarginate apically, arms filiform or lorate, $1.2-2.5 \mathrm{~mm}$ long, apically slightly widened, with large flat viscidia.

\section{NOTES}

1. The collection Wight 3018 at Kew is here designate as the lectotype as it contains a large number of complete plants, and also because duplicates are found in several other herbaria.

A herbarium sheet containing collections by Johnson (from Coonoor in southern India) and Jerdon (from Goodaloor in southern India), originally in Herb. Wight and later deposited in Kew, was in the past apparently mistaken for one of the types of $D$. neilgherrensis, but was clearly referred to $D$. tripetaloidea by Wight himself (Wight, 1851).

2. No specimen or illustration of D. papuana could be traced in the present study. However, Kraenzlin's description appears to match the present concept of D. neilgherrensis.

3. Disperis palawensis was described by Tuyama (1939) as Stigmatodactylus? palawensis based on a fruiting specimen, and as soon as flowering material became available correctly transferred to the genus Disperis. Rauschert (1983) made the new combination Pantlingia palawensis (Tuyama) Rauschert, which simply follows from the synonymy of Stigmatodactylus Maxim. ex Makino and Pantlingia Prain. It is not known to me whether Rauschert was aware of the combination as Disperis palawensis. In any case, $P$. palawensis is a superfluous name, as it is based on a misidentification of fruiting material.

4. Disperis tripetaloides is known from Madagascar, Seychelles, Mauritius, La Réunion and Rodrigues (La Croix et al., 2002). Although the species is rather similar to D. neilgherrensis in its alternate leaves and its flowers with a shallow hood made up of a narrow median sepal and broadly-lunulate and marginally reflexed petals, it differs clearly in its lip structure. However, Lindley (1939), in his description of D. tripetaloides, erroneously referred Sri Lankan material to this species and this name was therefore commonly used in later treatments. The error was only noticed by Moore in Baker (1877), and subsequently Trimen (1885a) described a new species D. zeylanica (which is here regarded as synonymous with D. neilgherrensis). 
5. Disperis teleplana F. Maek. was listed as a synonym of D. siamensis Rolfe ex Downie by Maekawa (1974) while recording the latter species from the island of Iriomote (Ryukyu islands, Japan). Maekawa cited D. teleplana as "in sched. Herb. Univ. Tokyo", implying that this name appears on herbarium sheets but was never published.

6. It appears that Disperis monophylla Blatter has never been published. There is a type specimen at Kew, collected by Blatter \& Hallberg with the number 345. A typewritten description (barcoded K000078866) which is attached to this type sheet is headed by "Disperis monophylla Blatt. sp. nov. (Orchidaceae-Ophrydeae-Corycieae) Recedit a Disperide zeylanica ...", then continues with a lengthy description and also cites the number 345. Interestingly, this description is identical with the one published by Blatter (1928: 522) under the name D. neilgherrensis, but without any mention having been made of the name monophylla; i.e. this type-written description must have been the manuscript used for publication. It is not clear whether the name D. monophylla was left out in error or intentionally. The apparently first published record of the name D. monophylla is a mention by C.E.C. Fischer in the same year (Fischer, 1928), where he considered it different from D. neilgherrensis.

7. A herbarium sheet at Kew bears the name Disperis sulphurum. The name was apparently never published but one of the specimens on the sheet is Wight 173 from the Nilgiri Hills, which is presumably one of the collections used as material for D. neilgherrensis Wight (fide J. Manning).

8. The name Disperis lunata is hand-written on several herbarium sheets in W; in most of these the name was later replaced by $D$. neilgherrensis. It was apparently also not published.

\section{DISTRIBUTION}

Disperis neilgherrensis has been recorded in India (southern: Madras, Tamil Nadu ${ }^{1}$ and Mysore, 33 collections examined in the present study; ?northern: see below); Sri Lanka (central provinces, 9 examined); Thailand (southern, northern and eastern, 2 examined); Hong Kong (island of Lantau, 2 examined); southern Taiwan (2 examined); southern Japan (Ryukyu islands, not examined, fide Maekawa, 1974); the Caroline Island Pulau (1 examined); the Philippines (southern and eastern parts of Luzon, 2 examined); Indonesia (Java, Flores, Moluccas and Irian Jaya, 5 examined) and Papua New Guinea (Torricelli and Finisterre Range, 1 examined). Throughout the distribution range it can be presumed that the species is more widespread. Two collections were made by Lobb in Khasia (Meghalaya in northern India) (specimens at $\mathrm{K}$ and W). Although in both cases only photocopies have been seen, it is obvious that the specimens in question are in fact Disperis ${ }^{2}$ species. These collections appear to have been overlooked by subsequent workers as this locality is not cited in a recent flora treatment of the Indian orchids (Pradhan, 1976).

1) The name of the species is derived from the Nilgiri Hills in Tamil Nadu.

2) Both were originally identified as D. neilgherrensis but this could not be verified here. 


\section{HABITATS AND ECOLOGY}

The plants grow in leaf litter or in moss on rocks on the forest floor and in grassy places. Most of the available altitude records are from between 600 and $2000 \mathrm{~m}$, but altitudes are lower in the Philippine and Taiwanese populations (and presumably also in the plants from Pulau) which grow between 250 and $700 \mathrm{~m}$. In most localities the plants are rare (or perhaps overlooked due to their small size), but in some collections from Sri Lanka and India the plants were referred to as 'locally abundant'.

Flowering times are diverse throughout the distribution range, probably as a result of climatic conditions. The specimens from India and Sri Lanka were collected in flower mostly between April and September; in Thailand, Hong Kong and Taiwan in July and August; in Java in January and February; and in Pulau and the Philippines in September. New Guinea specimens were collected in flower in April and September.

\section{VARIATION}

Disperis neilgherrensis varies enormously in the size of all of its parts. Specimens from India and Sri Lanka are the most robust overall, ranging from 80 to 280 (to 380) $\mathrm{mm}$, with lateral sepals between 8 and $15 \mathrm{~mm}$. Specimens from further east are considerably smaller, mostly ranging from 60 to $140 \mathrm{~mm}$, with lateral sepals between 5 and 7 $\mathrm{mm}$. The smallest specimens are those from Hong Kong (40-70 mm; lateral sepals 5-7 mm) and the Philippines (40-75 mm; lateral sepals c. $5 \mathrm{~mm}$ ). Also the type of D. siamensis (Kerr 1987) from northern Thailand is very small (40-80 mm; lateral sepals $5.5-6.5 \mathrm{~mm})$.

Leaves are alternate, and no variation in this respect occurs. However, it is interesting to note that subopposite leaves are found in young and non-flowering specimens. The number of leaves ranges from one to three, and that of the flowers from one to five (rarely to ten), apparently as a result of growing conditions. The flower structure is constant, with shallow hood with reflexed lateral margins, narrow median sepal, broadly lunulate petals, basally fused lateral sepals, narrow lip claw fused to the gynostemium, stalked and forwards-projecting lip blade and uniform gynostemium architecture, including simple rostellum arms. The measurements of all floral organs are subject to considerable variation.

The structure of the lip appendage, which is generally regarded as taxonomically highly informative in Disperis, is not entirely uniform in D. neilgherrensis. It consists generally of two narrow diverging processes next to each other, but the exact shape and orientation of these processes differs among the populations. In the eastern parts of the distribution area from Thailand and Indonesia to Japan and New Guinea the two processes constantly have the shape of more or less horizontally spreading horns. In contrast, in some of the examined Indian material the two processes are narrowly oblong and clearly ascending lobes. Although the structure is difficult to interpret in dry herbarium specimens, there appear to be occasional intermediate forms, and also the absence of differences in other sets of characters does not support a taxonomic separation. It is left to future students who have access to fresh or pickled material of more Indian specimens to re-examine the exact variation of the lip appendage, and to decide whether the recognition of a subspecies or variety would be justified. 


\section{LIP MORPHOLOGY}

The free lip portion generally has the form of a letter T or Y, with two spreading or ascending processes, and a slender lobe with a median tomentose hump projecting forwards. As also in the African and Madagascan Disperis species with a similar lip, the terminology of its various parts was somewhat confused in the past. In D. neilgherrensis previous workers have interpreted the lip either as 1) a two-lobed organ, with the spreading or ascending arms referred to as lip lobes and the median projecting organ as an appendage (Wight, 1844-1845, 1851; Hooker, 1894; Pradhan, 1976); or as 2) a three-lobed organ, with the spreading or ascending arms referred to as side lobes and the median projecting organ as the midlobe (Comber, 1990; Chen et al., 1999).

A correct interpretation would obviously require detailed ontogenetic investigations which have not been carried out as yet. Proceeding from comparative studies of many African Disperis species and other Orchidaceae-Coryciinae (Kurzweil, 1991; Kurzweil \& Linder, 1991), it is here suspected that the lip of D. neilgherrensis is essentially unlobed, has a bilobed appendage in the form of two processes and a stalked rotund blade with a central tomentose callus. This lip interpretation was also suggested by La Croix \& Cribb (1995: 232, t. 75) in the tropical African D. johnstonii Rolfe.

\section{RELATIONSHIP}

Although a sound phylogeny of the entire genus is not yet available, a few preliminary comments on the possible relationship of Disperis neilgherrensis to the rest of the genus appear appropriate. Several tropical African, Madagascan and Mascarene Disperis species share a similar flower morphology with $D$. neilgherrensis (narrow median sepal, open hood, basally fused lateral sepals, callose and stalked lip blade, two-lobed lip appendage) and may be closely related. Morphologically closest are D. cordata Sw. from Mauritius and La Réunion and D. johnstonii Rolfe, D. togoensis Schltr., D. mozambicensis Schltr. and D. reichenbachiana Rchb.f. from tropical Africa (in D. mozambicensis no material has been seen here; the close relationship was noted by Summerhayes, 1931). All of the aforementioned species have a very similar lip but most differ from $D$. neilgherrensis in the exact shape of their hood. Disperis tripetaloides (Thouars) Lindl. from Madagascar, the Seychelles, La Réunion, Mauritius and Rodgrigues as well as D. katangensis Summerh. from tropical Africa also have a similar flower structure and are probably also close relatives, but differ by an only weakly two-lobed lip appendage. Summerhayes (1931: 385) suggested that D. katangensis Summerh. and D. mozambicensis Schltr. are closer related to the Asian Disperis species than to the African taxa, but unfortunately no arguments for this theory were given.

\section{ACKNOWLEDGEMENTS}

I express my sincere thanks to Dr. J. Manning (South African National Biodiversity Institute) and Dr. K. Steiner (California Academy of Sciences, USA) for providing photocopies from overseas herbaria and libraries, and the former also for commenting on the manuscript. I am indebted to Dr. J.P. Roux for help in many ways, and to Mr. B. Jagger for his assistance in obtaining literature. I am furthermore grateful to the curators of AAU, AMES, BM, C, K, L, S, TAIF, TI and US for the loan of herbarium specimens, and to Dr. K.M. Matthew ( $\dagger$, RHT) for donating two collections of 
Disperis neilgherrensis. The curators of the herbaria B, HK, PDA and W are gratefully acknowledged for sending digital images or photocopies. Mr. Dorte Boesen (Nordic Journal of Botany) kindly granted copyright permission to re-use Fig. 1.

\section{REFERENCES}

Baker, J.G. 1877. Flora of Mauritius and the Seychelles. Reeve \& Co., London.

Blatter, E. 1928. A list of orchids, with some new species from the High Wavy Mountains (Madura District). J. Bombay Nat. Hist. Soc. 22: 518-523.

Chen, S.C., Z.H. Tsi \& Y.-B. Luo. 1999. Native orchids of China in colour. Science Press, Beijing \& New York.

Comber, J.B. 1990. Orchids of Java. Bentham-Moxon Trust, Royal Botanic Gardens Kew.

Downie, D.G. 1925. Contributions to the flora of Siam. Additamentum XVII. Kew Bull. 1925: 404-423.

Fischer, C.E.C. 1928. Flora of the Presidency of Madras, 8. London.

Fukuyama, N. 1936. Studia Orchidacearum Japonicarum. VIII. Orchidaceae Formosae et insulae Kôtô-syo novae atque criticae. Bot. Mag. (Tokyo) 50: 16-24.

Geerinck, D. 1984. Orchidaceae (part I). In: Flore d'Afrique centrale. Jardin Botanique National de Belgique.

Hooker, J.D. 1894. Flora of British India, 6. Reeve \& Co., London.

Hu, S.Y. 1972. Disperis lantauensis S.Y. Hu. Chung Chi J. 11: 17-19.

Jayaweera, D.M.A. 1981. Orchidaceae. In: M.D. Dassanayake \& F.R. Fosberg (eds.), A revised handbook to the Flora of Ceylon, 2: 4-386. Amerind Publishing Co., New Delhi.

Kraenzlin, F. 1900. Disperis. Orchidacearum genera et species, 1: 822-852. Mayer \& Müller, Berlin.

Kurzweil, H. 1991. The unusual structure of the gynostemium in the Orchidaceae-Coryciinae. Bot. Jahrb. Syst. 112: 273-293.

Kurzweil, H. \& H.P. Linder. 1991. A comparative study of the floral morphology in the genus Disperis (Orchidaceae). Beitr. Biol. Pflanzen 66: 433-477.

La Croix, I., J. Bosser \& P.J. Cribb. 2002. The genus Disperis (Orchidaceae) in Madagascar, the Comores, the Mascarenes and the Seychelles. Adansonia, sér. 3, 24: 55-87.

La Croix, I.F. \& P.J. Cribb. 1995. Orchidaceae. In: G.V. Pope (ed.), Flora Zambesiaca, 11 (1). Flora Zambesiaca Managing Committee, London.

Lindley, J. 1839. Disperis. The genera and species of orchidaceous plants: 369-372. Ridgways, London.

Liu, T.-S. \& H.-J. Su. 1978. Orchidaceae. In: H.-L. Li, T.-S. Liu, T.-C. Huang, T. Koyama \& C.E. DeVol, Flora of Taiwan, 5: 859-1137. Epoch Publishing Co., Taipei.

Maekawa, F. 1974. A new species of Disperis from Iriomote Island. J. Jap. Bot. 49: 307-308.

Manning, J. 1999. Disperis. In: H.P. Linder \& H. Kurzweil, Orchids of southern Africa: 299-320. Balkema, Rotterdam.

Matthew, K.M. 1983. The flora of the Tamilnadu Carnatic. Tiruchirapalli.

Pradhan, U.C. 1976. Indian orchids: Guide to identification and culture, 1. Published privately.

Pradhan, U.C. 1979. Indian orchids: Guide to identification and culture, 2. Published privately.

Pridgeon, A. M., P. J. Cribb, M.W. Chase \& F. N. Rasmussen. 2001. Genera Orchidacearum, 2. Oxford University Press.

Rauschert, S. 1983. Beitrag zur Nomenklatur der Orchidaceae. Feddes Repert. 94: 433-471.

Rogers, R. S., H.J. Katz \& J.T. Simmons. 1982. R. Schlechter - Figuren-Atlas zu den Orchidaceen von Deutsch-Neu-Guinea. The Australian Orchid Foundation, Melbourne.

Schlechter, R. 1898. Monographie der Disperideae. Bull. Herb. Boissier 6: 800-821, 846-859, 905-955.

Schlechter, R. 1905. Microspermae. In: K. Schumann \& K. Lauterbach, Nachtr. Fl. Deutsch. Schutzgeb. Südsee: 69-234. Borntraeger, Leipzig.

Schlechter, R. 1911. Disperis philippinensis. Feddes Repert. Spec. Nov. Regni Veg. 9: 436.

Seidenfaden, G. 1969. Contributions to the orchid flora of Thailand. Bot. Tidsskr. 65: 100-162. 
Seidenfaden, G. 1977. Orchid genera in Thailand V - Orchidoideae. Dansk Bot. Ark. 31: 1-149.

Seidenfaden, G. \& T. Smitinand. 1958-1965. The orchids of Thailand - a preliminary list. The Siam Society, Bangkok.

Smith, J.J. 1914. Disperis javanica. Bull. Jard. Bot. Buitenzorg II, 14: 19-22.

Smith, J.J. 1922. Disperis javanica. In: Tafeln javanischer Orchideen. Bull. Jard. Bot. Buitenzorg III, 5: t. 21.

Summerhayes, V.S. 1931. African orchids, II. Kew Bull. 1931: 378-390.

Trimen, H. 1885a. Notes of the flora of Ceylon. J. Bot. 23: 238-245.

Trimen, H. 1885b. A systematic catalogue of the flowering plants and ferns indigenous to or growing wild in Ceylon. George J.A. Skeen, Colombo.

Tuyama, T. 1939. Stigmatodactylus? palawensis Tuyama. Bot. Mag. (Tokyo) 53: 57-58.

Tuyama, T. 1940. Disperis palawensis (Tuyama) Tuyama. Bot. Mag. (Tokyo) 54: 267-268.

Verdcourt, B. 1968. Disperis. In: V.S. Summerhayes, Orchidaceae (part 1). In: E. Milne-Redhead \& R.M. Polhill (eds.), Flora of Tropical East Africa: 216-230. Crown Agents for Oversea Governments and Administrations, London.

Wight, R. 1844-1845. Disperis tripetaloidea. Icones Plantarum Indiae Orientalis, 3. Madras.

Wight, R. 1851. Disperis neilgherrensis. Icones Plantarum Indiae Orientalis, 5. Madras.

\section{INDEX TO SPECIMENS EXAMINED}

Where a collection is not clearly identified by a particular collector's number, the herbarium number is indicated (the herbarium abbreviation is the first entry in the brackets).

Baretto 295; 299 - Barnes 1241; 1330; 1879 - Beddome 8110; 8111; 8112 - Bernardi 15604 - Blatter \& Hallberg 345 - Bourne 5252; 5402.

?Cummin $16(\mathrm{~K})$.

Elmer 17355 - Evershed s.n. (BM 000048039); s.n. (BM 000048041).

Gamble 16965 - Gough s.n. (BM 000048040).

Ho-Ming H. Chang 5851 - Hohenacker 1572.

Jayaweera 59 - Jerdon s.n. (K H2003/01816 6) - Johnson s.n. (K H2003/01816 6).

Kerr 1987.

Larsen FTP 925; s.n. (C L 99/2003: 2) - Tsan-piao Lin 208 - Lobb s.n. (K s.n.); (W 47194).

Matthew RHT 23412; 24130; 62601; 62653 - Matthew \& Paramasivan RHT 24131 - Maxwell 931 - Mayar 381 - Merrill 4215.

Nicolson, Saldanha \& Ramamoorthy 189.

Perrotet 1102.

Ramamoorthy 1864; 1920 - Ridley 280.

Schlechter 18221; s.n. (AMES 18041); s.n. (AMES 18242); s.n. (B 100089413$)$ - Schmid 910 - Schmutz 4333; 4593; 4727 - Stocks, Law \& c. 1543; s.n. (AMES [number not legible]); s.n. (K H2003/01816 11); s.n. (K H2003/01816 14); s.n. (L 0323042).

Thwaites 2363 - Tuyama (TI M03 - 05).

Walker 180 - Wight 173; 3018; s.n. (W 47195); s.n. (BM 000812122); s.n. (K H2003/01816 16); s.n. (PDA s.n.).

\section{NOTE ADDED IN THE PROOF}

I am grateful to Paul Ormerod for drawing my attention to the overlooked name Disperis walkerae Rchb.f. (Linnaea 41 (1877) 101) which is based on a colour sketch held in the herbarium of the Royal Botanic Gardens Kew with the number H2003/01816-1. It is not clear whether the manuscript name $D$. walkeriana Rchb.f. (listed as a synonym of Schlechter's (1898) D. neilgherrensis Wight) refers to the same specimen although it is likely that it is merely an orthographic variant. However, it is evident from the above-mentioned drawing of D. walkerae and from Schlechter's synonymy regarding $D$. walkeriana that both can in fact be ascribed to $D$. neilgherrensis Wight as delimited in the present paper. 